\title{
Letter regarding "In consideration of subspecialty training in forensic anthropology for pathologists"
}

\author{
Derek Congram
}

Accepted: 27 May 2014/Published online: 16 July 2014

(C) Springer Science+Business Media New York 2014

Dr. Obenson laments a lack of forensic anthropological expertise in his country (Canada) [1]. I am encouraged that he recognizes the need, albeit sporadic in most districts. However, his article fails in two respects: his valuation of the gravity of the problem and his proposed solution.

In Dr. Obenson's own city there are two university-based biological anthropologists with doctorates who teach forensic courses. Further, a well-established forensic anthropologist who directs a Master of Science degree program in forensic anthropology and who collaborates with local medico-legal investigators is approximately $300 \mathrm{~km}$ away, which by Canadian standards is equivalent to being a next-door neighbor [2]. Elsewhere in Canada forensic anthropologists routinely travel over $500 \mathrm{~km}$ to work on cases. Dr. Obenson is not "compelled" to analyze skeletonized remains without anthropological assistance, nor should any forensic scientist practice beyond their expertise [3]. In Canada and other countries part of the problem is a lack of knowledge of available experts. For this, forensic anthropologists share some responsibility by way of their lack of professional organization [4].

Dr. Obenson's proposed solution of anthropology certification for pathologists will almost certainly create more problems. For years there has been active debate in Europe among the Forensic Anthropology Society of Europe (FASE) about certification. On continental Europe, biological anthropology is typically taught in university departments of biology and medicine, which has allowed medical students to receive limited training in skeletal anatomy. After protracted debate and criticism, FASE decided to allow those who have practiced "forensic anthropology" for the past 10 years-typically pathologists- to continue doing so (the so-called "older

D. Congram $(\bowtie)$

901-35 Charles Street, Toronto, ON M4Y 1R6, Canada

e-mail: dcongram@gmail.com generation" [5]). Although there is no guarantee that this older generation has and will continue to practice forensic anthropology in a qualified way, this seems to be a token gesture made by FASE to appease the old guard. In contrast, the "younger generation" of mostly biological anthropologists, will be subjected by FASE to written and practical exams for certification. By this process, and by their reliance on two U.S. board-certified forensic anthropologists (not pathologists) as adjudicators, FASE demonstrates that forensic anthropology must be professionalized and must also be practiced by anthropologists. Should we dismiss these notions and opt for Dr. Obenson's fasttrack forensic anthropological education for pathologists, we would be moving backwards. Speed-training for forensic anthropology will produce experts that will be no more effective at forensic anthropological analysis than tele-/photo-analysis by true experts.

\section{References}

1. Obenson K. In consideration of subspecialty training in forensic anthropology for pathologists. Forensic Sci Med Pathol. 2014;10:114-5.

2. St. Mary's University, Forensic Studies Faculty and Staff. http:// www.smu.ca/academics/forensic-studies-faculty-and-staff.html. Accessed 25 May 2014.

3. Goudge ST. Inquiry into pediatric forensic pathology in Ontario. Queen's printer for Ontario. 2008. http://www.attorneygeneral.jus. gov.on.ca/inquiries/goudge/report/v1_en_pdf/Vol_1_Eng_vi.pdf. Accessed 25 May 2014.

4. Gruspier K, Rogers T. Forensic anthropology. In: Pollanen MS, Bowes MJ, VanLaerhoven SL, Wallace J, editors. Forensic science in Canada: a report of multidisciplinary discussion. University of Toronto, Centre for Forensic Science and Medicine; 2012. p. 21-30. http://www.forensics.utoronto.ca/Assets/LMPF+Digital+Assets/ Forensic+Science+in+Canada.pdf. Accessed 25 May 2014.

5. Forensic Anthropology Society of Europe, certification scheme. http://forensicanthropology.eu/index.php/activities/fase-certificationprocess. Accessed 25 May 2014. 